\title{
Information and Communication Technology Integration in Different Online Learning Strategies to Facilitate Self-Directed Learning Experience
}

\author{
Suzan Atia Mostafa Alsaid
}

\section{ABSTRACT}

\begin{abstract}
Online learning is one among the foremost broadly speaking used terms, that has passed within the pitch of education at the side of IT, students, and college need quick and simple access to new technical and academic methods.

The online learning methods objects are primarily meant to be used by students for self-study. to boot, instructors will use on-line resources to supplement their room teaching.

So, this study discusses several on-line methods that may be applied and investigate in school rooms and live their effectiveness. that an intermingled learning strategy approach, computer-based learning approach, on-line learning vs offline learning (Ubiquitous Digital Information), and Team-based learning (TBL), From the table, lead to the present analysis we are able to conclude that the excellent strategy is mixed learning that provides the proportion of the height then follow by computer-based learning, so team-based learning, finally present digital learning.
\end{abstract}

Keywords: online learning, learning strategies, blended learning, computer, based learning, ubiquitous digital information, team based learning

Published Online: March 31, 2021

ISSN: $2736-5492$

DOI : $10.24018 /$ ejcompute.2021.1.2.8

Suzan Atia Mostafa Alsaid Taif University, Saudi Arabia (e-mail: sama2m20002000@ gmail.com )

\section{INTRODUCTION}

Online learning is one of the most generally used terms, which has pass in the field of education together with IT. Educational institutions make this type of education a part of their long-term plans and they make massive asset in this teaching and learning method. [28]

students and faculty desire fast and easy access to new practical and educational strategies. They would like to greatly interact with each other and to use technology for better teaching and learning. They normally use information and communication technology to simplify the teaching and learning process. This propensity can be accomplished with online learning strategies.,

The online learning methods things square measure primarily supposed to be used by students for self-study. to boot, lecturers will use on-line resources to enhance their schoolroom teaching.

So, for any on-line learning methods application, together with e-learning, instructors got to mirror however the technology may be integrated into the info with such methods in on-line learning inventions. So, this study discusses a few the net methods which will be applied and investigate in lecture rooms and live their effectiveness

On the one hand, the net data with success is repeatedly attention-grabbing the autonomous learning students to speedily update and increase their existing nature of information. [27]

Over the last periods, there has been a move in student learning activities from ancient types of teaching to different media that assignation online, distance, or electronic learning. [22]

As delineated by (Howlett,2009) [10] This online learning entrance provides options for making and commercial enterprise a range of learning ways appropriate for education. for straightforward formation and distribution of effective online ways, the academics will merely transfer existing digital documents, like PowerPoint slides and image files. Besides, learners will merely generate on-line material employing an inherent authoring tool, by that users will create sites with text and transmission designers.

\section{PROBLEM IDENTIFICATION}

There is a vital need for change with concentrating and shifting from teacher-centered towards interactive, learnercentered approaches. Shifting the focus towards the studentlearner involves accenting the role of the students.

During the past decade, it's been seen a notable unfold within the use of on-line learning ways in several areas of education. on-line learning professions have accrued 
intensely as proved by the trend in issued studies over the past decade.

Educational programs apply on-line learning for several of those cases. however, there has been a requirement to figure relating to the barriers that students face and therefore the solutions to boost meeting with on-line learning ways. [16]

Therefore, the present study aims to fill this gap. In some occurrences, on-line learning stands alone because of the essential, main course of study of a program. additional normally, on-line learning tools area unit mechanisms of the course of study, supplementing ancient face-to-face room and academic actions. over the net from a desktop or mobile device, outside of the room, or alternative ancient learning environments. [7]

However, the progress of the simplest practices for info and communication technology addition in numerous on-line learning ways to facilitate autonomous learning expertise remains in its starting. Educators and learners want direction to assist them to decide on the suitable on-line learning ways to use in numerous instructional settings and to participate effectively in separate courses and across the course of study.

\section{RESEARCH QUESTION}

1) What are the instructional design approaches for online learning strategies?

2) What is the effectiveness of a blended learning strategy approach?

3) What is the effectiveness of the computer-based learning approach?

4) What is the effectiveness of Online learning vs offline learning (Ubiquitous Digital Information)?

5) What is the effectiveness of Team-based learning (TBL)?

\section{THE PURPose}

This study indicates and highlights basic knowledge to understand the online learning strategies. Besides, the current study objects to explore students' learning notice, satisfaction, learning experience, and act on the cognitive feature, while little research was found to investigate their research degree or cognitive loading. So current study aims to:

1) Implement effective teaching strategies in education.

2) Explored students' learning interest/satisfaction

3) Facilitate instructors and students to appear for on-line resources to improve teaching and learning within the correct program.

4) Explore the many probably for on-line ways.

5) Describe the capabilities that students continually a failure, the areas that students notice most fascinating, and what areas that we'd like to revamp in order that it helps students accomplish well

6) Explore the compensations and challenges of victimization online learning

7) Explore the necessities to contemplate for the undefeated and effective application of online tools and their incorporation into curricula.

8) The growing role of on-line and IT technologies in education

9) Participate in e-learning in education can amendment the landscape of however students self-direct learn.

\section{IMPORTANCE}

1) Enhance learning methods for college students by providing them with independent and personal learning environments

2) Explore the features that best expect students' achievement in education.

3) Define the association between online and offline learning.

4) Define the strategies that have the most efficient influence on students' learning

5) Support faculty members need to devise ways for integrating e-learning into their curricula.

6) The application of online learning within a school will encourage faculty to remain up to date on technological advances.

7) Sharing e-learning into teaching applies.

8) Confirm a strong suggestion base for or against e-learning in education

\section{TOOLS}

1) A survey to evaluate the effectiveness of a blended learning strategy approach

2) A survey to evaluate the effectiveness of computer-based learning approach,

3) A survey to evaluate the effectiveness of Online learning vs offline learning (Ubiquitous Digital Information),

4) A survey to evaluate the effectiveness of Team-based learning (TBL)

\section{THE ONLINE LEARNING STRATEGIES}

\section{A. Blended Learning Strategy Approach}

İt is a technique to mix the benefits of online and offline learning strategies, referred to as homogenized learning a combination of online and offline learning may well be the foremost effective for education. [9]

A blending learning environment uses many learning technologies, like on-line learning mechanisms, that are wont to improve traditional room instructions, these learning objects also can be constant and reused to get an internet course. Thus, the training objects are often won't sustenance numerous learning activities and learning objectives [3].

So, the study integrates an online learning material with each schoolroom and side learning in a kind of attentiongrabbing way. on-line components might follow face-to-face learning to support or extend learning. basically, this elearning entry supports individual learning, whereby students access learning materials primarily based upon their own learning wants through blackboard content.

To support such a learning atmosphere, students have a customized account service, wherever they will use the resources of interest the study follow these heads to develop the blended learning approach:

Blended learning will facilitate larger sharing within the interactive than face-to-face learning activities.

1) The blended learning approach conveyance autonomous learning into the middle of attention

2) These approaches apply real-life issues as attention for learning

3) Blended learning together with an online course followed by a live workshop

4) The on-line module was interactive, multimedia, and raised accessibility and management over the content. 
5) The on-line course allowed students to realize awareness of the topic

6) Many of the technological skills needed to develop effective on-line materials

7) The students will carriage queries and find answers associated with the content of on-line resources by forum discussion or to share info helpful for students.

8) Providing on-line discussion boards to facilitate cooperative learning.

9) Blended learning facilitates the training and provides students with larger confidence and data

10)Online learning permits students to accumulate basic data as preparation for a face-to-face room or side online learning.

11)This style makes the simplest use of the time spent and the quality of the academic engagement with educators and with different students.

12)The academics are trained in a way to structure and facilitate in-class and on-line activities that target the request of the data and skills that student's area unit showing within the on-line materials.

13) The blended learning methodology changes the role of an instructor from providing info to encouraging, motivating, simplifying, arguing, and assessing achieving learning objectives and capabilities.

\section{B. Computer-Based Learning Approach}

A computer-based learning technique is open learning areas that are addicted to learner-learner, and learner-teacher interaction, it's important to be clear however accessible the academics are going to be. we tend to create programming once specific academics are online thus there's continuously a presence, or that the tutors can only answer to notes that match the course track. A further approach to acting with learners is to host live question and answer sittings, wherever academics are online at a selected time and learners understand that if they post a comment throughout this era, they're going to receive a fast reply. Several software explanations will support this growth and can have some technical support to verify the session goes affording to set up. (20) though the time after you hold the session will vary, to supply for all learners recording the session for asynchronous viewing by those in numerous time zones would be a much-appreciated technique. As an alternative, live sessions might be run multiple times day by day, or colleagues from collaborating establishments around the world may run them to supply for specific teams. It is open access courses created by analysis with computer-based learning approaches the potential role of computer-based learning strategies means that various range of learners will enrich the course outside, what might be delivered by the host institution alone, by sharing their information and knowledge with others [13].

A study framework for delivering computer-based learning approaches follows these guides:

1) Enroll during a computer-based learning approach to completely gain on-line the web the net\} surroundings taking part that's generally in line with student's knowledge base to gaining insight into this technique of online learning.

2) Learn from alternative computer-based learning ways enthusiasts Before getting on the event stage, confirm you're totally tuned in to the facts and time commitment concerned.
3) Develop a computer-based learning approaches topic.

4) The topic ought to be targeted on area neighborhood a district a regional locality a vicinity a partial section that are deeply obsessional regarding as this interest can bump into within the resources the analysis develops. However, we tend to rigorously take into reflection the supposed target market and therefore the computerbased learning ways length.

5) Employee, a committed and excited team to support the computer-based learning approaches development and delivery a team of compatible and committed individuals ought to be incorporates.

6) The team ought to encompass a lead tutorial to progress an acceptable program, write lecture scripts for videobased content, produce learning objects, and set assessment queries. using a group of adjunct equals to assist within the analysis procedure of this material is additionally urged to substantiate the content is well accessible and delivers the meant learning objectives.

7) Support network ought to embrace members WHO will step during at transient notice and facilitate transport the course in a backup and lecturers WHO will move with the learners on the stage once the course is running.

8) Develop a program map to guide the content reach develop program map, and build the target market, what educational level the content goes to cover.

9) To generate a transparent project arrange it ought to be clear that the event of a computer-based learning technique may be a complex and inefficient method.

10) It's important that the computer-based learning ways delivery is committed to the course's style and is rich with the number of contents that must be made.

11) It is important is critical is important\} to rise that making skilled videos and alternative kinds of media needs significant time and this must be scheduled.

12) Concept an acceptable assessment profile once considering what assessments your computer-based learning ways can contain the foremost necessary thought is measurability [25].

13) Computer-based learning ways typically fascinate learners, and it's necessary that we will deliver feedback that's timely and proper.

14) The most public format is automatic quizzes, which might be settled throughout the program and permit learners to observe their development.

15) Promote course with a transparent and attractive message once the beginning date for the course.

16) Provide an adjunct surrounding for learners to move with most computer-based learning ways. [23]

17) Diverse learners can move with computer-based learning ways to variable levels.

18) Develop a large analysis and analysis strategy for postcourse reflection and development.

19) Share information to any enhanced computer-based learning and received useful and regeneration.

\section{Online Learning vs Offline Learning (Ubiquitous Digital Information)}

To prepare the qualified learner for today's atmosphere within which the web offers ubiquitous digital data, Offline learning, or traditional room teaching, represents teaching within the pre-internet era. though some sorts of data technology have already been applied to support instruction, traditional teaching ways needed that teaching and education 
ought to get a place at constant time and place. on-line learning, additionally referred to as internet-based learning or web-based learning, doesn't have time and house range, and thus, makes teaching and learning separate via internet-based data delivery systems. each on-line and offline teaching is generally employed in an educational activity. so, this study planned to explore and discuss the potential factors across these 2 teaching ways that may cause variations in ineffectiveness:

The effectiveness of on-line learning is influenced by numerous problems. Some problems produce barriers for online learning, like body matters, social communication, educational skills, technical skills, learner motivation, time and support for studies, technical issues, cost, and access to the net. [17]

1) Other factors might end in low-quality online learning, as an example, associate degree ineffective style and arrangement of multimedia materials. [18]

2) The effective analysis of on-line and offline teaching in education, therefore, ought to rely upon associate degree inclusive reflection of however they're used across teams. It ought to all be assessed as well as the training goals, style properties of the training materials, analysis of learning outcomes.

3) However, this newer evidence still recommends that online learning may be as effective as offline one for coaching licensed health care professionals, however, the overall effects of on-line learning were little and given no important variance in comparison to offline teaching (8).

4) This study style targeting data and ability outcomes.

5) The objective of this organized analysis was to evaluate however on-line learning compared to offline learning the effectiveness of on-line learning varied, that is as or more practical than offline learning for a few target data and skills and also the students. To avoid the potential limitations of on-line learning in hinge the education knowledge and skills.

\section{Team-based learning (TBL)}

Team-based learning raises the applying of data through individual work, little cluster work and cooperation, and instant feedback. Learners get information through self-study and completion of needed reading assignments. [26]

During TBL sessions learners apply this data in a very sequence of problem-solving training controlled by a coach. this might embody Individual Passion, cluster Readiness, and application exercises. [4]

It shifts the course goal from knowing to applying, students shift from passive to the active learner, and responsibility for learning shifts from teacher to student, a careful assessment of the challenges, outcomes, and problems associated with TBL has to be studied. to make sure that TBL is going to be with success enforced, some areas ought to be investigated. a smart backing from the management. [15]

1) The TBL course was designed, Students were strategically organized into permanent groups.

2) Each TBL unit begins by finding out assigned learning material (reading materials, website tutorials, video demonstrations, etc.) before class.

3) They were additionally specified regular and timely feedback on their performance. Following this method, every team is assigned with appl

4) Students' Reaction towards TBL
5) Students were comfy operating in groups and satisfied with the team members' participation.

6) Students appreciated learning in groups and were developing the understanding and skills required to figure fruitfully in task-groups. [2]

7) TBL in an exceedingly focused course presentation appeared to be notably engaging for the best students of the year, creating them even a lot of fortunate within the key examination.

8) Even the scholar's World Health Organization usually learned on your own extraordinarily valued learning in groups, therefore rising the kind and skills fascinating to figure fruitfully in task-groups. improvement in student engagement with course content, therefore, increased their understanding. [11]

9) They believed that it'd facilitate them to perform higher in their exams. several students read TBL favorably regardless of their grades. [12]

10) Incorporation of TBL supports active learning, essential thinking of foundational information exploitation massive schoolroom cooperative learning processes, which can raise their interest in learning. [5]

11) TBL is an active technique primarily during an extremely reduced and concept-based course

12) 20- to 30-minute interactive webinar argument(s) with varied on-the-ground and general leaders.

13) An on-line discussion forum to facilitate sharing ideas (19)

14) An on-line repository for distributing materials associated with worth inventions. the training network employed a non-public Google Community. [24]

15) The replacement of a complete lecture-based course of study recovery placement, Given the trials of college time promise associated fitting TBL sessions inside an eventful inhabitant and school workday. [14]

16) The course of study information is an important part of placement coaching and is typically educated during a lecture setting. [1]

17) Challenges display by work hour restrictions, increasing demands, reduced time for teaching, and restricted effectiveness of lectures as a method of participating learners have resulted in the need for active learning approaches. [6]

18) Team-based learning (TBL) could be a dynamic learning method. [21]

\section{SAMPLING AND METHODS}

This study follows some a procedure to achieve its aims which be presented as following.

\section{A. First Stage}

A random sample of students were chosen about 150 students.

\section{B. Second Stage}

1) The course of study Development tutorial style

1) The tutorial style is outlined as "the method of determinant what ways of instruction area unit best for desired changes in student information and skills for particular course content and specific student

2) Instructional style strains the organized method of developing instructional or coaching programs

3) The tutorial style consists of 5 phases: analysis, design, development, implementation, and analysis. 
These phases produce the standards for the look observe that meets the quality of the advised ways.

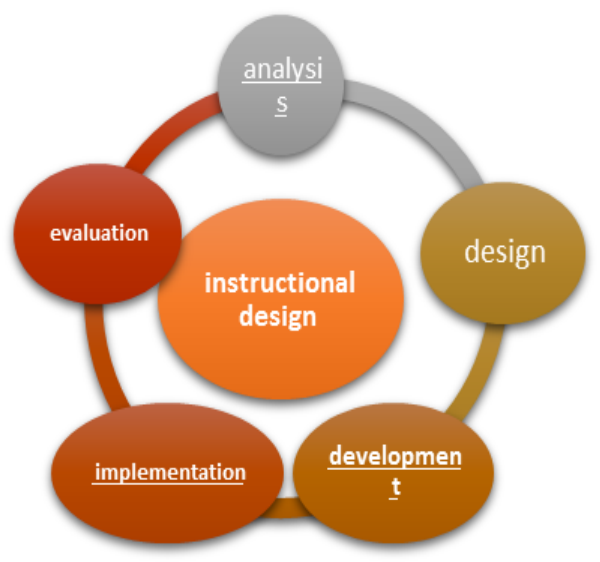

Fig. 1. instructional design process

\section{2) Learning desires assessment}

The aim of a need's assessment is to search out what students got to understand to perform the designed behavior desires assessment was conducted to spot specific content in methods and outline the acceptable content for every strategy

3) Analysis

The analysis purpose among methods is that the formulation of environmental and structure descriptions and identification of resources, content, and assessment of learning desires and ability needs, classification of learner and analysis of goals and objectives for varieties of data, skills, or learning obligatory.

\section{4) Learner options}

Learners have completely different preferences for what they learn and the way they learn. Some prefer to learn what they understand as relevant or sensible whereas others prefer to take time to or desires. Face-to-face, massive cluster instruction sessions might meet the requirements of some students however not others preferring to find out one by one at their own pace and reflection on their learning. So, the study distributes the training strategy consistent with learner options and characteristics.

\section{5) Style and Development}

In the style and development stages, the main focus was on formulation goals and elaborate learning objectives, sequencing content, choosing media, submission of learning and tutorial principles consistent with appropriate learning strategy additionally designing for assessment and analysis of learning.

\section{6) Setting Goals and Objectives}

After the analysis, the general goals of the content and learning objectives for every strategy were placed the taxonomy was wont to outline and confirm specific, measurable objectives that will function as a guide for each student learning.

\section{7) Sequencing of Content}

It was a challenge for college students to work out what resources they must use, and why and after they ought to use them. it absolutely was determined in every strategy, within the strategy, connected queries are explained at intervals the training context and data resources acceptable for various varieties of strategy are introduced.

\section{8) Making Tutorial Methods}

According to tutorial systems, associate degree tutorial strategy was established according to the conditions include activities that facilitate strategy aspects of the training method

\section{9) Development}

A content management system adopted, offers the aptitude of observation and following students' usage activities and access to course materials consistent with every strategy.

\section{0) Evaluation}

Evaluation is employed for the aim of constructing a judgment concerning the worth, excellence, or result of academic methods.

Both formative and summation analysis are a crucial part of tutorial style summation evaluation is bothered with mensuration the effectiveness of the merchandise when its implementation.

a) Formative evaluation

The formative analysis power-assisted style and development of the information. As a result, many enhancements were created, together with a visible roadmap for navigating the strategy and a guide for the exploitation of the strategy.

b) Summative evaluation

The summation analysis is to evaluate an academic product's overall price, quality, or final value.
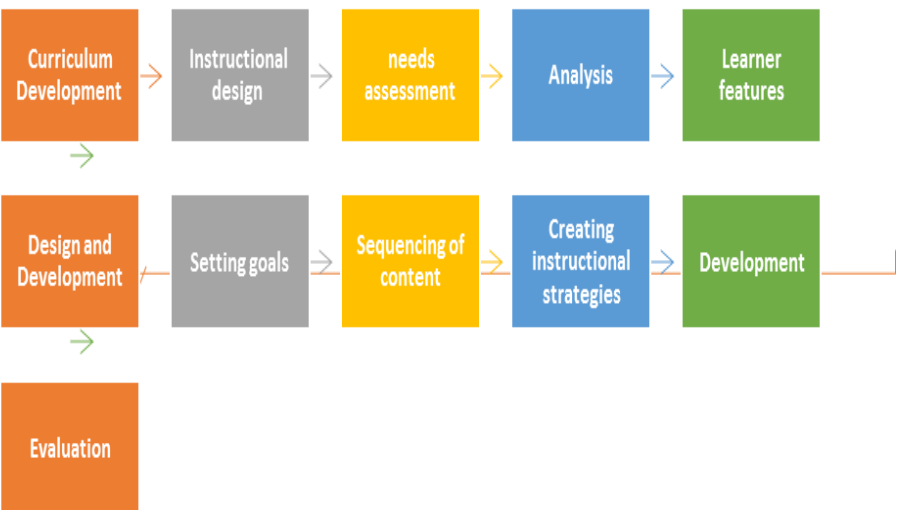

Fig. 2. learning strategy development

\section{Third Stage}

A strategy analysis survey issued to assess students' reaction to the strategy, and a self-assessment check is provided for college students to measure their own learning outcomes. Since the implementation of the strategy.

\section{Fourth stage}

Further critical efforts were done, as well as interviews with students to provide their opinions on the utility of the strategy, analysis of the long-run impact of the strategy on students' and observation of student participation and contributions to every strategy. 


\section{Statistical ANALYSIS AND Discussion}

TABLE I A BLENDED LEARNING STRATEGY EFFECTIVENESS

1- a blended learning strategy effectiveness $\%$

\begin{tabular}{|c|c|c|c|c|c|}
\hline items & $\begin{array}{l}\text { strongly } \\
\text { agree }\end{array}$ & agree & $\begin{array}{l}\text { not } \\
\text { decided }\end{array}$ & disagree & $\begin{array}{l}\text { strongly } \\
\text { disagree }\end{array}$ \\
\hline the advantages of integrated learning are combining online and offline learning strategies & 42 & 31 & 5 & 15 & 7 \\
\hline This strategy is the response to your desires & 23 & 23 & 16 & 21 & 17 \\
\hline The mixture of on-line and offline learning may well be the foremost effective for college boy education & 32 & 24 & 16 & 16 & 12 \\
\hline This strategy is employed to improve advanced room directions & 41 & 22 & 15 & 17 & 5 \\
\hline $\begin{array}{l}\text { It supports interaction among users by providing on-line discussion boards to facilitate cooperative } \\
\text { learning }\end{array}$ & 22 & 25 & 17 & 13 & 23 \\
\hline It will facilitate the educational skills & 32 & 32 & 17 & 13 & 6 \\
\hline It provides students with larger confidence and information & 22 & 21 & 31 & 12 & 14 \\
\hline $\begin{array}{l}\text { Online learning permits students to accumulate basic, foundational information as preparation for a face- } \\
\text { to-face room or side learning. }\end{array}$ & 25 & 18 & 23 & 21 & 13 \\
\hline $\begin{array}{l}\text { blended learning is often particularly helpful for learners with various instructional or experiential } \\
\text { backgrounds }\end{array}$ & 17 & 22 & 14 & 22 & 25 \\
\hline $\begin{array}{l}\text { Blended learning was interactive, multimedia, and raised accessibility and management over the content } \\
\text { and pace of learning for extremely various learners }\end{array}$ & 25 & 23 & 18 & 19 & 15 \\
\hline $\begin{array}{l}\text { it changes the role of an educational teacher from providing information to encouraging, motivating, } \\
\text { facilitating, leading the discussion, and assessing achieving learning objectives and competencies. }\end{array}$ & 26 & 24 & 18 & 13 & 19 \\
\hline $\begin{array}{l}\text { it Is transportation self-directed learning into the middle of attention involves the learner as an energetic } \\
\text { participant }\end{array}$ & 28 & 22 & 23 & 12 & 15 \\
\hline $\begin{array}{l}\text { This design makes the most effective use of the time spent and also the quality of the academic } \\
\text { engagement with the professional instructor(s) and with alternative students. }\end{array}$ & 15 & 20 & 40 & 22 & 3 \\
\hline Average & $29.3 \%$ & $26.1 \%$ & $20.7 \%$ & $17.6 \%$ & $13.7 \%$ \\
\hline
\end{tabular}

The student's satisfaction to the mixture between on-line learning and of-line strategies $73 \% \mathrm{~m}$ additionally they satisfy that the strategy accomplishes their desires with share fortysixth, additional over they accept as true with The mixture of on-line and offline learning and it would be the foremost effective for collegian education. Also, this strategy is employed to improve ancient room directions fifty-six, else it supports individual learning, wherever in students access learning materials primarily based upon their own learning desires sixty-fourth. additionally thereto will facilitate the training of skills, and provides students with larger confidence and information forty-third, the web learning permits students to accumulate basic, foundational information as preparation for a face-to-face room or side learning. $43 \%$, conjointly the emulsified learning strategy is interactive, multimedia, and raised accessibility and management over the content and pace of learning for these teams of extremely numerous learners $48 \%$, it changes the role of an educational teacher from providing information to encouraging, motivating, facilitating, leading the discussion, and assessing achieving learning objectives and competencies.50\%.it Is delivery independent learning into the middle of attention involves the learner as a vigorous participant five hundredths, This style makes the best use of the time spent and therefore the quality of the academic engagement with the skilled instructor(s) and with different students. $35 \%$.

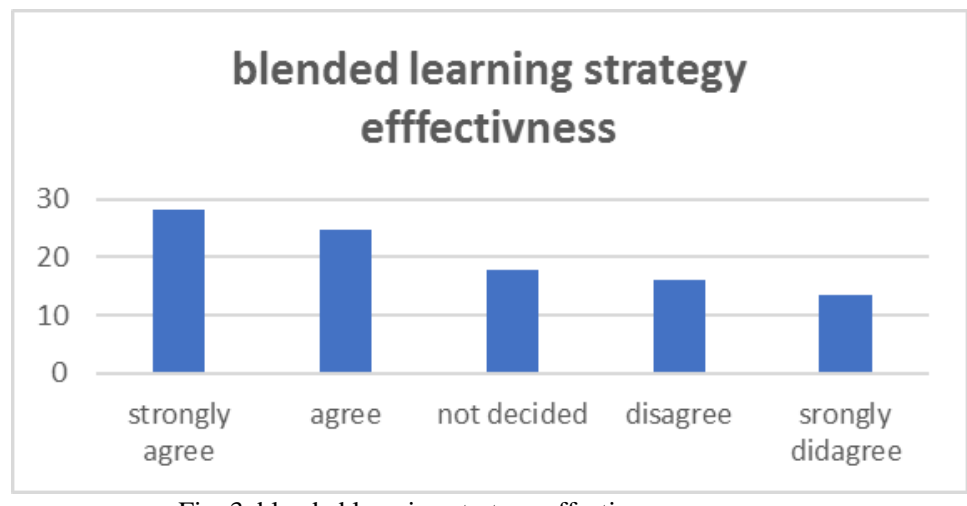

Fig. 3. blended learning strategy effectiveness

The students gave $29.3 \%$ to strongly agree, whenever they gave $26.1 \%$ to agree also they gave $20.7 \%$ to not decided and they gave a low percentage to disagree $17.6 \%$ and strongly disagree $13.7 \%$, that mean the was satisfy with blended learning strategy in education. 
TABLE II: COMPUTER-BASED LEARNING EFFECTIVENESS

2-computer-based learning effectiveness

\begin{tabular}{|c|c|c|c|c|c|}
\hline items & $\begin{array}{l}\text { strongly } \\
\text { agree }\end{array}$ & agree & $\begin{array}{l}\text { not } \\
\text { decided }\end{array}$ & disagree & $\begin{array}{l}\text { strongly } \\
\text { disagree }\end{array}$ \\
\hline It is obsessed with learner-learner, and learner-mentor interaction, & 41 & 22 & 15 & 17 & 5 \\
\hline It interacts with learners is to host live question and answer sessions, & 31 & 33 & 17 & 14 & 5 \\
\hline It uses numerous software package solutions that will support this development & 22 & 25 & 17 & 13 & 23 \\
\hline $\begin{array}{l}\text { the time after you hold the session will vary, to supply for all learners recording the } \\
\text { session for asynchronous }\end{array}$ & 25 & 23 & 18 & 19 & 15 \\
\hline $\begin{array}{l}\text { The live sessions might be run multiple times day by day or colleagues from } \\
\text { collaborating establishments }\end{array}$ & 26 & 24 & 18 & 13 & 19 \\
\hline the education literature is well inhabited with computer-based learning approaches & 28 & 22 & 15 & 16 & 19 \\
\hline $\begin{array}{l}\text { The Enrollment on computer-based learning approaches to completely gain the web } \\
\text { environment taking part is helpful }\end{array}$ & 24 & 32 & 15 & 15 & 14 \\
\hline $\begin{array}{l}\text { It diode educational to develop an acceptable program, write lecture scripts for video- } \\
\text { based content, produce learning objectives, and set assessment queries. }\end{array}$ & 33 & 15 & 22 & 16 & 14 \\
\hline The development of computer-based learning approaches is a fancy and long method & 26 & 33 & 12 & 15 & 14 \\
\hline $\begin{array}{l}\text { It is committed to the course's style and is evident in the number of contents that must } \\
\text { be created }\end{array}$ & 16 & 23 & 22 & 25 & 14 \\
\hline $\begin{array}{l}\text { It Provides a collateral atmosphere for your learners to move with most computer-based } \\
\text { learning approaches }\end{array}$ & 18 & 19 & 22 & 21 & 20 \\
\hline Different learners can move with computer-based learning approaches & 40 & 22 & 15 & 17 & 6 \\
\hline Average & $27.5 \%$ & $24.4 \%$ & $17.3 \%$ & $16.7 \%$ & $14 \%$ \\
\hline
\end{tabular}

It is addicted to learner-learner, and learner-mentor interaction, it's necessary to be clear however accessible the mentors are going to be sixty-three, It interacts with learners is to host live question and answer sessions, wherever instructors are on-line at a selected time and learners recognize that if they post a comment throughout this era sixty-fourth, It uses varied software system solutions will support this development and can most likely need to own some technical support to confirm the session goes consistent with arranging.48\%, The live sessions may well be run multiple times day by day, or colleagues from collaborating establishments around the world may run them to cater for specific teams.50\%. the education literature is well inhabited with computer-based learning approaches50\%. The Enrollment on computer-based learning approaches to completely gain the net setting taking part is useful56\%. It desires a team that encompasses a lead education to develop an acceptable course of study, write lecture scripts for videobased content, produce learning objectives, and set assessment queries.48\%. the event of computer-based learning approaches will be a posh and long process $59 \%$. it's committed to the course's style and is obvious with the quantity of content that must be produced $39 \%$. It provides a subsidiary setting for your learners to act with most computer-based learning approaches thirty-seventh. totally different learners can act with computer-based learning approaches to variable levels, et al. partaking solely with resources that match their own specific desires.62\%.

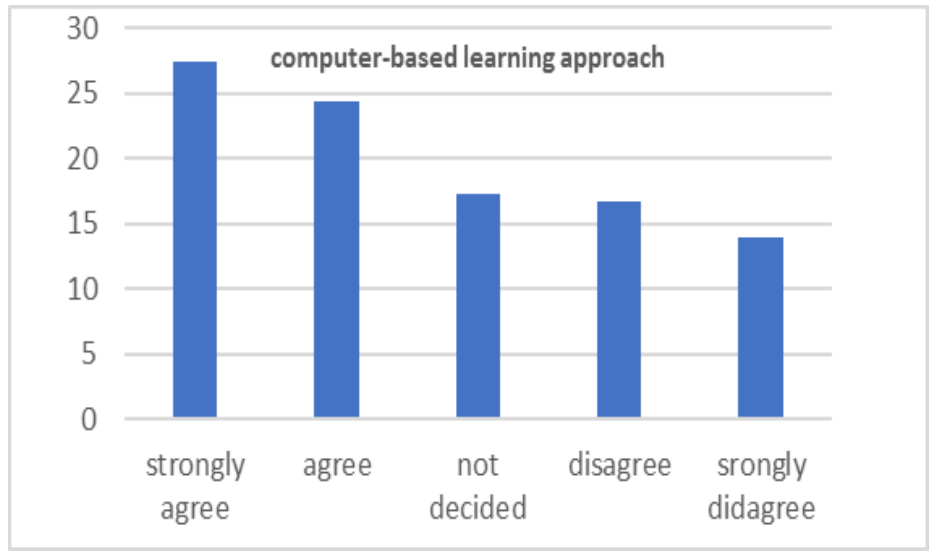

Fig. 4. computer-based learning effectiveness

The students gave $27.5 \% \%$ to strongly agree, whenever they gave $24.4 \%$ to agree also they gave $17.3 \%$ to not decided and they gave a low percentage to disagree $16.7 \%$ and strongly disagree $14 \%$, that mean the was satisfy with blended learning strategy in education. 
TABLE III: ONLINE LEARNING VS OFFLINE LEARNING (UBIQUITOUS DIGITAL INFORMATION)

\begin{tabular}{|c|c|c|c|c|c|}
\hline items & $\begin{array}{l}\text { strongly } \\
\text { agree }\end{array}$ & agree & $\begin{array}{c}\text { not } \\
\text { decided }\end{array}$ & disagree & $\begin{array}{l}\text { strongly } \\
\text { disagree }\end{array}$ \\
\hline It makes teaching and learning separate via internet-based info delivery systems & 32 & 22 & 15 & 17 & 14 \\
\hline $\begin{array}{l}\text { Some factors produce barriers for on-line learning, like body problems, social } \\
\text { interaction, educational skills, technical skills, learner motivation, time and } \\
\text { support for studies, }\end{array}$ & 22 & 23 & 22 & 16 & 17 \\
\hline $\begin{array}{l}\text { It ought to rely on a comprehensive thought of however they're used across } \\
\text { teams. }\end{array}$ & 15 & 27 & 28 & 15 & 15 \\
\hline online learning worked higher than offline one for education, & 21 & 23 & 26 & 17 & 13 \\
\hline $\begin{array}{l}\text { It is simpler than offline learning for a few target data and skills and therefore } \\
\text { the students. }\end{array}$ & 21 & 24 & 22 & 18 & 15 \\
\hline Average & $22.2 \%$ & $23.8 \%$ & $22.6 \%$ & $16.6 \%$ & $14.8 \%$ \\
\hline
\end{tabular}

It makes teaching and learning separate via internet-based info delivery systems $54 \%$. Some factors produce barriers for on-line learning, like body problems, social interaction, educational skills, technical skills, learner motivation, time and support for studies, technical issues, and access you'll overcome it forty fifths. It ought to rely on a comprehensive thought of however they're used across teams. It ought to all be assessed together with the educational goals, style properties of the educational materials, analysis of learning outcomes. $42 \%$. on-line learning worked higher than offline one for undergraduate education $44 \%$. it's more practical than offline learning for a few target information and skills and therefore the students. $45 \%$.

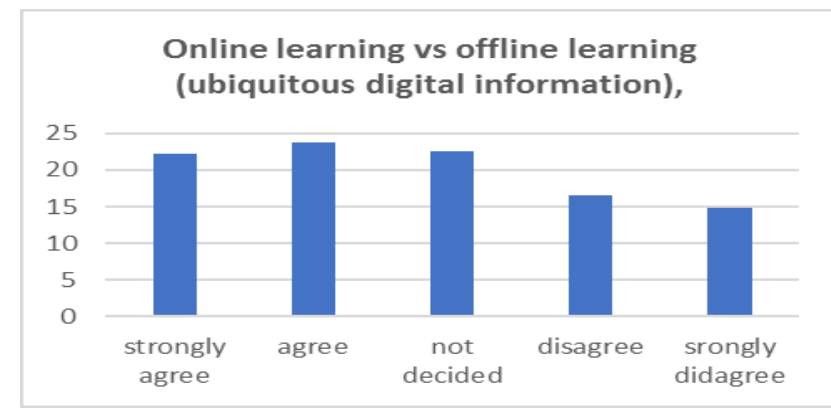

Fig.5. Online learning vs offline learning (ubiquitous digital information)

The students gave $22.2 \%$ to strongly agree, whenever they gave $23.8 \% \%$ to agree also they gave $22.6 \%$ to not decided and they gave a low percentage to disagree $16.7 \%$ and strongly disagree $14 \%$, that mean the was satisfy with blended learning strategy in education.

\begin{tabular}{|c|c|c|c|c|c|}
\hline \multicolumn{6}{|l|}{ 4-Team-based learning (TBL) } \\
\hline items & $\begin{array}{l}\text { strongly } \\
\text { agree }\end{array}$ & agree & $\begin{array}{c}\text { not } \\
\text { decided }\end{array}$ & disagree & $\begin{array}{l}\text { strongly } \\
\text { disagree }\end{array}$ \\
\hline It provides frequent and timely feedback on students' performance. & 31 & 33 & 17 & 14 & 5 \\
\hline $\begin{array}{l}\text { Students appreciated learning in groups and were developing the understanding } \\
\text { and skills }\end{array}$ & 41 & 22 & 15 & 17 & 5 \\
\hline $\begin{array}{l}\text { Students were comfy operating in groups and satisfied with the team members' } \\
\text { participation. }\end{array}$ & 31 & 33 & 17 & 14 & 5 \\
\hline $\begin{array}{l}\text { improvement in student engagement with course content so increased their } \\
\text { understanding }\end{array}$ & 22 & 25 & 17 & 13 & 23 \\
\hline $\begin{array}{l}\text { Incorporation of } \mathrm{TBL} \text { supports active learning, essential thinking of } \\
\text { foundational data exploitation massive classroom cooperative learning } \\
\text { processes, }\end{array}$ & 32 & 32 & 17 & 13 & 6 \\
\hline $\begin{array}{l}\text { the replacement of a whole lecture-based information placement, Given the } \\
\text { challenges of school time commitment TBL sessions }\end{array}$ & 22 & 23 & 22 & 16 & 17 \\
\hline Challenges expose by work hour restrictions, reduced time for teaching, & 15 & 27 & 28 & 15 & 15 \\
\hline \multirow[t]{2}{*}{ Team-based learning (TBL) is a vigorous learning methodology } & 21 & 23 & 26 & 17 & 13 \\
\hline & $26.8 \%$ & $27.2 \%$ & $19.8 \%$ & $14.8 \%$ & $11.1 \%$ \\
\hline
\end{tabular}




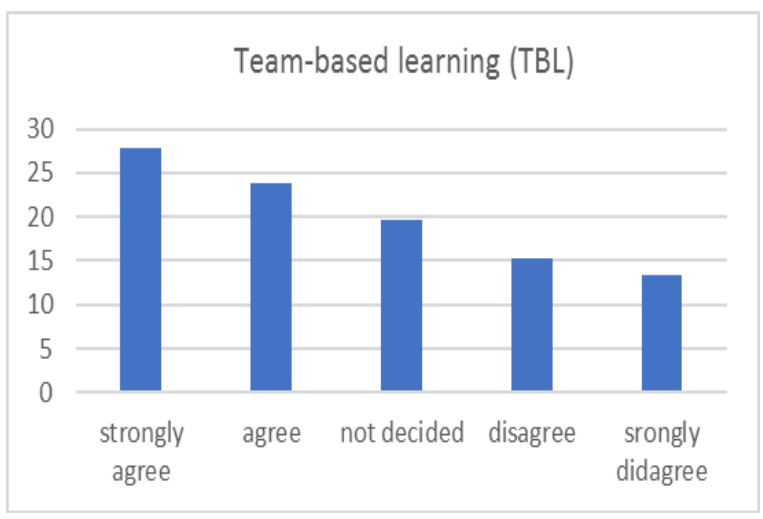

Fig. 6. Team-based learning (TBL)effectiveness

\section{CONCLUSION}

TABLE V: THE STRATEGIES COMPARISON AND CONCLUSION

\begin{tabular}{|l|l|l|l|l|l|}
\hline & $\begin{array}{l}\text { strongl } \\
\text { agree }\end{array}$ & $\begin{array}{l}\text { agre } \\
\mathrm{e}\end{array}$ & $\begin{array}{l}\text { not } \\
\text { decide } \\
\mathrm{d}\end{array}$ & $\begin{array}{l}\text { disagre } \\
\mathrm{e}\end{array}$ & $\begin{array}{l}\text { Strongl } \\
\mathrm{y}\end{array}$ \\
\hline $\begin{array}{l}\text { 1-a blended } \\
\text { learning }\end{array}$ & 28.15 & 24.6 & 17.6 & 16 & 13.5 \\
\hline $\begin{array}{l}\text { 2-computer-based } \\
\text { learning }\end{array}$ & 27.5 & 24.4 & 17.3 & 16.7 & 14 \\
\hline $\begin{array}{l}\text { 3- ubiquitous } \\
\text { digital } \\
\text { information }\end{array}$ & 22.2 & 23.8 & 22.6 & 16.6 & 14.8 \\
\hline $\begin{array}{l}\text { 4-Team-based } \\
\text { learning }\end{array}$ & 26.8 & 27.2 & 19.8 & 14.8 & 11.12 \\
\hline
\end{tabular}

From the table result in the current research we can conclude that the comprehensive strategy is blended learning which give the heights percentage then follow by computerbased learning, and then team-based learning, finally ubiquitous digital learning. So, the current study is agreed with other studies such as (Jamie Costley,2020) [29] the Purpose of This study aims to look at how the use of perceptive learning strategies might reasonable the association.

Design/methodology/approach this study found that the utilization of psychological feature methods moderates this relationship. "This shows that the utilization of cognitive methods will facilitate overcome unclear instruction and facilitate to provide higher levels of student learning. Originality/value - among online learning environments". conjointly (Tsai-Yun Mou, 2020) [30] This study sightsaw preservice and in-service infancy educators' on-line educational learning opinions and techniques. Design/methodology/approach attention cluster argument was accepted regarding the event of the questionnaires. The survey results showed that in-service academics typically control additional elegant learning opinions than the preservice academics altogether rulers. Also, in-service academics answered with the next level of on-line educational learning methods than the preservice academics did. relating to their online experiences.

Moreover (Mohd Muslim Md Zalli,2020) [31] specializing in - Massive Open on-line Course (MOOC) is among unsettling innovations in on-line learning environments that attract a vital interest among students. MOOCs need learners to be actively concerned and to utilize a separate method of self-regulated learning. The progress of an activity model for on-line self-regulated learning (SRL) has been found to be lacking when put next to the normal, face-to-face context. This analysis has the target of developing a model for measure on-line self-regulation ways in Malaysian MOOCs. Further, this study recommends many suggestions relating to the relevance of the activity model with alternative variables associated with teaching and learning in MOOC" additionally (muir,2020)(32) study Simplification ways for enhancing the educational and engagement of on-line students there square measure increasing worries regarding low student retention and progression rates for on-line students compared with on-campus students. equally, (Lee.2020) [33] study examines the relationships between self-efficacy, task value, and therefore the use of self-regulated learning ways by huge open online course (MOOC) learners from a social psychological feature perspective. And There was a statistically vital distinction within the use of self-regulated learning ways between learners WHO possessed high selfefficacy and people WHO possessed low self-efficacy. Ether This study was designed (SUCAROMANA, U,2020) [35] to "discuss the net learning ways that enclosed motivation, selfmonitoring, net skill, net anxiety, and concentration, of Thai EFL college man students. The results specific the extent of net anxiety was high, whereas the extent of motivation, degree of self-monitoring, level of net skill, and level of concentration may be at a mean level once engaged in on-line learning. additionally, there was a vital distinction between gender with the web anxiety, whereas there was no vital distinction relating to students' learning accomplishment altogether on-line learning strategies".

\section{REFERENCES}

[1] Accreditation Council for Graduate Education. (2017). Common Program Requirements. https://www.acgme. org/Portals/0/Passes/Program Requirements/CPRs .pdf. Accessed December 11,

[2] Alizadeh M, Mirzazadeh A, Parmelee DX, Peyton E, Janani L Hassan zadeh G, Nedjat S:(2017) Uncover it, students would learn leadership from team-based learning (TBL): the effect of guided reflection and feedback. Med Teach.;39(4).

[3] Al-Eraky MM, Donkers J, Wajid G, Van Merrienboer JJ. (2015) Faculty development for learning and teaching of professionalism. Med Teach 2015; 37: S40-6. https://doi.org/10. 3109/0142159X.2015.1006604.

[4] Balwan S, Fornari A, DiMarzio P, et al. (2015) Use of team-based learning pedagogy for internal medicine ambulatory resident teaching. J Grad Med Educ.;7(4):643-648

[5] Cevik AA, Elzubeir M, Abu-Zidan FM, Shaban S. :(2019). Teambased learning improves knowledge and retention in an emergency medicine clerkship. Int $\mathrm{J}$ Emerg Med.;12(6). https://doi.org/10.1186/s12245019-0222-2

[6] Cooper AZ, Richards JB. Lectures for adult learners (2017): breaking old habits in graduate education. Am J Med.;130(3):376-381.

[7] Cook D, Dupras D. A practical guide to developing effective web-based learning. J Gen Intern Med. (2004) 19(6):698-707.

[8] Davis J, Chryssafidou E, Zamora J, et al. (2007) Computer based teaching is as good as face to face lecture-based teaching of evidence-based medicine: a randomized controlled trial. Med Teach;7(1):23.

[9] Garrison DR, Vaughan ND. (2007) Blended Learning in Higher Education: Framework, Principles, and Guidelines. New York (NY): John Wiley \& Sons; 2007; ix-xi.

[10] Howlett D, Vincent T, Gainsborough N, Fairclough J, Taylor N, Vincent R. (2009) Integration of a case-based online module into an undergraduate curriculum: what is involved and what is effective? e-Learning.;6(4):372-84. 
[11] Keshmiri F, Rahmati A, Ghafarrahimi Amin A, Faezi T:(2016) Validating and assessing the reaction of students toward teambased learning. Acta Med Iran.;54(12):806-11.

[12] Kim RH, Song Y, Lindquist R, Kang HY: (2016). Effects of team-based learning on problem solving, knowledge, and clinica performance of Korean nursing students. Nurse Educ Today.; $38: 115-8$

[13] Milligan C, Littlejohn A. (2016). How health professionals regulate their learning in massive open online courses. Internet High Educ. 31:113-121

[14] McMullen I, Cartledge J, Finch E, et al. (2014). How we implemented team-based learning for postgraduate doctors. Med Teach;36(3):191-195.

[15] Michaelsen L, Sweet M, Parmalee D, editors. (2009) Team-based learning: small group learning's next big step. New directions in teaching and learning. Chichester, United Kingdom: John Wiley and Sons Ltd; p. 7-27.

[16] Muilen burg L, Berge Z. Student barriers to online learning:(2005) a factor analytic study. Distance Educ.;26(1):29 48.

[17] Muilen burg LY, Berge ZL. Student barriers to online learning (2005). a factor analytic study. Distance Educ.;26(1):29-48.

[18] Mayer RE. (2002). Multimedia learning. Psychol Learn Motiv.;41(1):85-139.

[19] Olsen LA, Aisner D, McGinnis JM, eds. (2017). The Learning Healthcare System. Washington, DC: National Academies Press 2007. https://www.ncbi.nlm.nih.gov/ books/NBK53494/ Accessed May 26,

[20] Pickering JP, Swinnerton BJ. Forthcoming:( 2017). An anatomy massive open online course as a continuing professiona development tool for healthcare professionals. Med Sci Edu.

[21] Peppelman RS, Liebert CA, Vegas DB, et al. (2016). A narrative review and novel framework for the application of team-based learning in graduate education. J Grad Med Educ.;8(4):510-517.

[22] Shachar M, Neumann Y.: (2016). Differences between traditional and distance education academic performances:a meta-analytic approach. The International Review of Research in Open and Distributed Learning [Internet]. Available from: http://www.irrodl.org/index.php/irrodl/article/view/153/704

[23] Swinnerton BJ, Morris NP, Hotchkiss S, Pickering JD. Forthcoming: (2016). The integration of an anatomy massive open online course (MOOC) into a anatomy curriculum. Anat Sci Educ. 10:53-67.

[24] Shah N, Levy AE, Moriates C, et al. :(2015). Wisdom of the crowd: bright ideas and innovations from the teaching value and choosing wisely challenge. Acad Med.;90(5):624-628.

[25] Subhi Y, Andresen K, Rolskov Bojsen S, Mørkeberg Nilsson P, Kong L.:(2014). Massive open online courses are relevant for postgraduate training. Dan Med J. 61: A4923

[26] Thibault GE. (2016). The importance of an environment conducive to education. J Grad Med Educ. (;8(2):134-135.

[27] Thompson P. The digital natives as learners: (2013). Technology use patterns and approaches to learning. ComputeEduc.;65(7):12-33.

[28] Triantafillou E, Pomportsis A, Georgiadou E. AES-CS:(2002). an adaptive educational system based on cognitive styles. Second International Conference on Adaptive Hypermedia and Adaptive Web-based Systems; Málaga, Spain.

[29] Jamie Costley. (2020). Using cognitive strategies overcomes cognitive load in online learning environments. Interactive Technology and Smart Education, 17(2), 215-228. https://doiorg.sdl.idm.oclc.org/10.1108/ITSE-09-2019-0053

[30] Tsai-Yun Mou, \& Chia-Pin Kao. (2020). Online academic learning beliefs and strategies: a comparison of preservice and in service early childhood teachers. Online Information Review, 45(1), 65-83. https://doi-org.sdl.idm.oclc.org/10.1108/OIR-082019-0274

[31] Mohd Muslim Md Zalli, Hasniza Nordin, \& Rosna Awang Hashim. (2020). Online Self-Regulated Learning Strategies in MOOCs: A Measurement Model. International Journal of Emerging Technologies in Learning, 15(8), 255-263. https://doiorg.sdl.idm.oclc.org/10.3991/ijet.v15i08.12401
Muir, T., Douglas, T., \& Trimble, A. (2020). Facilitation strategies for enhancing the learning and engagement of online students. Journal of University Teaching \& Learning Practice, 17(3), 1-17.

[33] Lee, D., Watson, S. L., \& Watson, W. R. (2020). The Relationships Between Self-Efficacy, Task Value, and SelfRegulated Learning Strategies in Massive Open Online Courses. International Review of Research in Open \& Distance Learning, 21(1), 23-39. https://doiorg.sdl.idm.oclc.org/10.19173/irrodl.v20i5.4389

[34] SUCAROMANA, U. (2020). A Study on the Online Learning Strategies among Thai EFL Undergraduate Students. Proceedings of the Multidisciplinary Academic Conference, 15-18.

[35] Puspanda Hatta, Yusfia Hafid Aristyagama, Rosihan Ari Yuana, \& Septi Yulisetiani. (2020). Active Learning Strategies in Synchronous Online Learning for Elementary School Students. IJIE (Indonesian Journal of Informatics Education), 4(2), 86-93. https://doi-org.sdl.idm.oclc.org/10.20961/ijie.v4i2.46019 